\title{
Challenges of Working-Class Education at Present: The Landless Workers' Movement Experience in Brazil
}

\author{
Célia Regina Vendramini \\ Federal University of Santa Catarina, Brazil \\ Janaina Stronzake and Judite Stronzake \\ Rural Landless Workers Movement, Brazil \\ Sérgio Paulo Morais \\ Federal University of Uberlândia, Brazil
}

\section{Introduction}

In this essay, we address the educational program and experiences of the Brazilian Landless Workers' Movement (MST), as found in its camps, settlements, schools, and political training courses. One of the most active organized social movements in Brazil during the last thirty years, the MST combines political struggle with the organization of worker-controlled enterprises and educational opportunities for landless workers and their families. We begin with an excerpt from a report by one of us (Janaina Stronzake), which illustrates the ways in which the material conditions of an MST encampment led to a different kind of school, focused on the needs of students from the countryside.

It was 1986, my teacher was called Iraci Salete Stronzake in the occupation of Imbuzinho Farm, municipality of Ortigueira, Paraná. We were about thirty to thirty-five children of different ages, from first to third grade, in a single classroom and a single teacher. There was no one else, we cleaned the classroom and desks by ourselves, we made lunch, sought water from a water spout, organized classes, and grew the vegetable garden. The "school" was a small tin-roof wooden shed, with a single division that separated the classroom from the kitchen. It was officially called "Emergency School Camellia II," but we have named it Rosa de Luxemburgo School. We split up into groups to arrange a schedule for studying, going to the vegetable garden, and eating. Our teacher was also a landless worker and was attending a course for teachers at night in the city. One of the most interesting activities we did at that time was creating a book of edible and medicinal plants of our region, and for that purpose we harvested seeds, leaves, flowers, bark, roots; we talked to many people, read other books and prepared our own educational materials on the subject to continue studying. There we learned not only Biology, Portuguese, Mathematics, Chemistry, but we strengthened our peasant identity and our ability to collectively build knowledge. 
The experience thus described, one of many that could be cited, is associated with MST's "Pedagogy of the Earth" and its traveling schools, which are encouraged and supported by the National Education Program for Agrarian Reform [Programa Nacional de Educação na Reforma Agrária] (PRONERA) in Brazil. From the spare canvas, grass, zinc, or open-sky schools in the camps through the postgraduate courses, to which the MST has sent students, and the international partners it has formed to assist its educational programs among the Brazilian peasantry, the MST has confronted and overcome numerous barriers while building a popular movement of agrarian reform. As part of this movement, education is both a principal goal and form of struggle.

The MST considers access to a high-quality, publicly provided secular education one of the conditions for the realization of popular agrarian reform. ${ }^{1}$ Indeed, it considers education to be a fundamental right of all people, to be provided where they live and concerned with the entire cultural inheritance of humanity. ${ }^{2}$ To achieve these goals for rural peoples requires public policies designed to ensure access to education in the countryside. According to the MST, these policies need to encompass a comprehensive program for youth and adult literacy; universal elementary education; expanding opportunities for vocational education, secondary and higher, with courses related to the needs of rural communities; expanding access to higher education, including at the graduate level; training and research in agroecology; scholarships for international exchange; and fostering research focused on agrarian reform in all its aspects. ${ }^{3}$

Based on the experience of the MST and its educational program, we consider below the challenges of educating the working class today, in the context of national and international attacks on workers' rights, drastic reductions in the funding for public education, and the criminalization of organized social movements. In this difficult environment, we see mobilizations in different parts of the world, where people are struggling to protect threatened social rights and to survive in a world of growing unemployment, informal labor relations, poor working conditions and substandard housing. For more than thirty years, the MST has sought to combine political, economic, and social struggles into one unified movement. Its ability to struggle and to organize is linked to its creation of productive enterprises inside its rural settlements, while they have become, in the words of David Harvey, "spaces of hope."4

In pursuit of these goals, the MST has explicitly sought to ensure that its members have the political, technical, and scholarly education they require. This education is provided by the movement itself, and in partnership with universities, municipal institutes, and schools linked to state and city networks. Today there are more than two thousand public education programs in MST camps and settlements, which serve 200,000 children and adolescents in primary and secondary education. The MST has also organized literacy programs, which have enabled 60,000 adults to learn to read and write. It has developed more than 100 undergraduate partnerships with colleges and universities around the country. ${ }^{5}$ 


\section{The Itinerant Schools in the Camps of the MST}

The main form of struggle used by the MST is the occupations of large tracts of land that are not assigned to productive use, followed by the establishment of a camp, in which hundreds or even thousands of families exert pressure for its expropriation and recognition from the National Institute for Colonization and Agrarian Reform (INCRA). The occupation and the settlements are great radical actions that challenge the private ownership of land. ${ }^{6}$ There are now approximately 150,000 families in MST camps around the country. ${ }^{7}$ To enable a large group of people to build and live in the camp requires considerable organization and discipline, as well as a lot of knowledge about how to govern collective life. Learning begins with the construction of shelter, which requires practical knowledge about how to protect from the bitter cold, wind, or heat. Then there is the need to provide safe drinking water, to construct adequate sanitation facilities, provide places to wash clothes and persons, and, finally, to build a school.

MST camp residents are organized into committees (food, health, safety, hygiene, education, etc.) and into neighborhoods of around ten families. The assembly is the highest level of camp authority. Residents are challenged to participate in assembly meetings, to write down their decisions, and then to commit them to memory. We observed workers with hands calloused by hard labor holding a pen to write and many accustomed only to take orders and obey standing up to express an opinion.

Schools inside the camps are called itinerant because they move when the camps move. A camp may move at any time and for many reasons: because they are evicted by the police or threatened by armed men; because families decided to occupy a different estate, go on a march, or engage in a different action; or for some other reason. As the camp moves, the school moves with it. They are created to "assist children, adolescents, youth and adults in roaming situation, as they are camping struggling for expropriation of unproductive land and implementation of the settlement." ${ }^{\prime \prime}$

Despite all the difficulties, the itinerant school is a strategic tool in the occupation and resistance process. ${ }^{9}$ During fieldwork research with ten itinerant schools in the state of Paraná (southern Brazil), Marlene Sapelli observed this process in action. One of the schools she studied has been responsible for the education of several MST leaders and educators, many of whom have gone on to earn college and postgraduate degrees. In one case, an eviction of several encamped families was thwarted because the school had so many children studying in it. MST schools also come in many forms and are self-organized and collectively managed, which places a greater emphasis on critical, collective, and useful knowledge. Indeed, itinerant schools can be found at MST congresses and meetings, at practical training courses, in public squares, on highways, and other places. 


\section{Settlements Schools and Their Relationship to Work}

The move from camp to settlement means a victory that brings many challenges and conflicts. The settlement consists of an expropriated area that has been recognized through INCRA. In their new life as settlers, the landless encounter a set of needs that were not part of their daily lives either in the camp or before. They are challenged to take on complex tasks, plan their lives and work, decide how to organize production (collective or individual), establish working farms, develop projects to get funding, seek technical assistance, and negotiate with external agents. They also need to think of houses, schools, health, roads, and so forth.

Some 460,000 families now live in settlements around the country. ${ }^{10}$ They not only have access to land, but also the opportunity to experiment with different forms of social organization. Some settlements organize cooperatives, associations, and other collectivist forms that are among the most advanced types of workers' organization. There are approximately 1,900 associations and 100 cooperatives in settlements that work in collective or semi-collective ways and have established sustainable and organic enterprises to grow crops without using pesticides. ${ }^{11}$

Settlement schools illustrate the conflict between the state's educational objectives and MST's goals for the education of the working class and its children. According to Istvan Meszáros, institutionalized education in a capitalist society is part of a broader process of "internalization," which is intended to ensure that the system is supplied with individuals of the sort it needs. ${ }^{12}$ Sandra Dalmagro has studied the contradiction between the MST's demand that the state provide universal elementary education throughout the country, including in rural areas, and its opposition to the form and content of the schools provided by the state. ${ }^{13}$ Many of these schools, especially those located in rural and remote areas, are far from providing a stimulating environment for study, discovery, and knowledge dissemination. At the same time, many of the schools organized by the workers themselves suffer persecution and criminalization.

In this difficult context, some schools manage to do important, even great things. There have been important initiatives, such as the Pedagogical Policy Project, which sought to involve local communities in efforts to integrate settlement realities into the school curriculum. Other efforts have included establishing a program of collective educators; organizing the school schedule to combine study time and work time; enabling students' practice of self-organization; designing a curriculum based on local reality in the manner of Brazilian educator Paulo Freire; and organizing a curriculum in interdisciplinary complexes, after the fashion of school communes established during the early years of revolutionary Russia. $^{14}$

According to a study by Natacha Janata, the Iraci Salete Stronzake School in the state of Paraná has made a difference from the moment it was founded in the settlement area where it is located. It has been known as a force in the 
struggle of the landless for their rights, even with all the limitations it faces as a formal institution under state control. ${ }^{15}$ The school has been a space where youth learn their own history and then often go on to participate in the struggles of the MST and other movements.

Here is how one Iraci student described her experience at the school:

The Iraci is a totally different school because it attempts to show more concern for the countryside ... [and] rescues the history of the settlement, trying to take it for everyone. It always tries to live in struggle, uniting students, and make the students know how to face the difficulties and life. Teachers and students struggle enough, they teach us to study, to fight, they encourage. I find it very important, because a student has to learn, even if it is not easy, he has to fight, learn to be strong ... I learned to be strong and Iraci School helped me. ${ }^{16}$

The MST defends an alternative conception of engaged education, which has been inspired by activists and educators who have lived this ideal, including Florestan Fernandes, Chico Mendes, José Marti, Zumbi dos Palmares, and Paulo Freire. Schools in the camps and settlements, in addition to being necessary for education of children and young people, should be different. They cannot be like traditional schools, which foster subservience, limit learning to the classroom, ignore the context of real life, and disregard the struggles of organized social movements.

\section{The Formation of Young Militants in Brazilian Public Universities}

To ensure continuing study is a significant element in the education of young MST activists, the MST and other organized social movements in Brazil have successfully demanded access to undergraduate and graduate education at Brazilian public universities for young workers and others. There they have been able to study education, history, law, agronomy, and other subjects and to obtain professional qualifications. In 2010, 33 state, regional, and federal universities were servicing 56 classes with 1,618 students enrolled. ${ }^{17}$ The National Education Program for Agrarian Reform (PRONERA), which is part of the National Institute for Colonization and Agrarian Reform in the Ministry of Agrarian Development, was established to assist young people and adults from agrarian reform settlements. From the time of its creation in 1998 until 2010, according to Débora Lerrer, 450,000 young people and adults graduated in basic education, vocational middle-level, and higher education and specialization courses. $^{18}$

Opening the universities to young rural workers has faced various obstacles, such as lawsuits filed by prosecutors to prevent or interrupt the continuity and completion of many courses. Such actions reveal the private character of the public sphere in Brazil, which is also evident in the difficulties that working-class children have when trying to gain access to and attend public 
universities. But the struggles of Brazilian social movements to open the universities has made it possible for young people to widen their experience, broaden and deepen their knowledge, interact with a range of other people, gain access to libraries, conduct research on development, and publish and participate in all the various activities (academic and cultural) that are part of the university routine.

\section{Popular Organization, Agrarian Reform, and Agroecology}

The importance of access to education for the MST is illustrated by its attention to "agroecology" as an alternative to the market-driven, corporate-dominated practices of agribusiness. Agroecology is the application of the principles of ecology to agricultural science (or "agronomy") to create sustainable agriculture systems. It developed slowly as an alternative to mainstream agronomy during the first half of the twentieth century. But with the rise of the environmental movement and growing concern over pollution, climate change, and corporate farming practices, it has recently become a flourishing academic subdiscipline, with programs in many universities across the globe.

MST joined with other agrarian reform movements around the world in 1993 to form La Via Campensia, now a network of more than 160 national and local organizations from 73 countries in Africa, Asia, Europe, and the Americas. Via Campensia is united in its support for agroecology and "food sovereignty," defined as "the right of peoples to healthy and culturally appropriate food produced through sustainable methods." Several agroecological education and research centers have already been established in Brazil, including the Iraci Salete Stronzake School (in Cantagalo) and the Ireno Alves dos Santos School (in Rio Bonito do Iguaçu), both of which are linked to the Sustainable Development and Training in Agroecology Center (CEAGRO). Other Brazilian centers where the study of agroecology and additional essential disciplines flourish include the José Gomes da Silva School, associated with the Technical and Research Institute of Agrarian Reform (ITEPA) in São Miguel do Iguaçu; the Milton Santos School in Maringá; the Latin American School of Agroecology (ELAA) in Lapa; the Florestan Fernandes National School (ENFF) in São Paulo. Centers outside Brazil include the Latin American Agro-Ecological Institute (IALA) in Guarani, Paraguay; the Institute of Latin American Agroecology (IALA) in Paulo Freire, Venezuela; the National School of Agroecology in Ecuador; and the Countryside Multidisciplinary University (UNICAM) in Argentina. ${ }^{19}$

In the MST and in Via Campensina more generally, we find a comprehensive educational strategy intended to secure access to knowledge and research for the landless who are struggling for access to land and for the right to practice a sustainable agriculture. If there is such an agriculture in our future, it will be won in significant measure by the struggles of the poor and the landless, who are teaching themselves and others not only how to obtain the land they need to support their families, but also how to preserve it. 


\section{NOTES}

1. MST, Programa Agrário do MST-Lutar, Construir Reforma Agrária Popular, VI Congresso Nacional (Brasília, 2014).

2. MST, Programa Agrário do MST, 45.

3. MST, Programa Agrário do MST, 45-47.

4. David Harvey, Espaços de esperança (São Paulo, 2004).

5. See http://www.mst.org.br (accessed May 11, 2015).

6 . Brazil is the second country in the world with the highest concentration of land. The Agricultural Census data released by IBGE in 2009 show that small farms (less than 10 hectares), which represents 47 percent of rural establishments, occupy only 2.7 percent of the occupied area. Large properties (more than 1000 hectares), which account for only 0.91 percent of the establishments, occupy 43 percent of the total area. Source: IBGE, Censo Agropecuário 2006 (Rio de Janeiro, 2009), available in: http://www.ibge.gov.br/home/estatistica/economia/agropecuaria/ censoagro/brasil_2006/Brasil_censoagro2006.pdf (accessed August 1, 2016).

7. See http://www.mst.org.br (accessed May 11, 2015).

8. MST, Itinerante: a escola dos Sem Terra-trajetórias e significados (Curitiba, 2008), 88.

9. Marlene L.S. Sapelli, "Escola do campo-espaço de disputa e de contradição: análise da proposta pedagógica das escolas itinerantes do Paraná e do Colégio Imperatriz Dona Leopoldina" (Ph.D. diss., Universidade Federal de Santa Catarina, 2013).

10. See http://www.mst.org.br (accessed May 11, 2015).

11. Ibid.

12. István Meszáros, Para além do capital: rumo a uma teoria da transição (São Paulo, 2002).

13. Sandra L. Dalmagro, "A escola no contexto das lutas do MST" (Ph.D. diss., Universidade Federal de Santa Catarina, 2010).

14. Moisey M. Pistrak, ed., A escola-comuna (São Paulo, 2003).

15. Natacha E. Janata, "Juventude que ousa lutar!: trabalho, educação e militância de jovens assentados do MST" (Ph.D. diss., Universidade Federal de Santa Catarina, 2012).

16. Interview granted to Natacha Janata on December 22, 2011. See Janata, "Juventude que ousa lutar," 230.

17. See http://www.mec.gov.br (accessed June 20, 2013).

18. Débora F. Lerrer, "Preparar gente: a educação superior dentro do MST," in Estudos Sociedade e Agricultura, ed. CPDA/UFRJ [Programa de Pós-Graduação em Desenvolvimento, Agricultura e Sociedade/Universidade Federal Rural do Rio de Janeiro] (Rio de Janeiro, v. 20, 2012).

19. Via Campesina. See http://www.laviacampesina.org/en (accessed August 1, 2016). 